\title{
EXAMINING THE CORRELATION BETWEEN ISLAMIC BANKS PROFITABILITY AND THE BUSINESS CYCLE IN INDONESIA
}

\author{
Mohammad Yusron Sholikhin ${ }^{*}$, Indri Supriani ${ }^{2}$, Rachmania Nurul Fitri Amijaya ${ }^{3}$ \\ *Corresponding Author \\ ${ }^{1}$ Faculty of Economics and Business, Universitas Airlangga, Jalan Airlangga No.4, Airlangga, Kec. Gubeng, Surabaya, \\ Indonesia, yusronsholikhin@gmail.com \\ ${ }^{2}$ Faculty of Economics and Business, Universitas Airlangga, Jalan Airlangga No.4, Airlangga, Kec. Gubeng, Surabaya, \\ Indonesia, indri.supriani-2018@pasca.unair.ac.id \\ ${ }^{3}$ Faculty of Economics and Business, Universitas Jember, Gang 5, Tegal Boto Lor, Sumbersari, Jember, Indonesia, \\ rachmanianers@gmail.com
}

\begin{abstract}
This study aims to examine the correlation between Islamic banks' profitability in Indonesia and the business cycle, which measured by composite leading Indicator (CLI). This study used several annual data covering the period from 2004-2018. This study utilizes Islamic banks profitability represent by Return on Asset (ROA) data as the dependent variable, CLI data as the dependent variable, and six control variables including Gross Domestic Product, Inflation, Financial to Deposit Ratio, Capital Adequacy Ratio, Non-Performing Finance, and Operating Costs Operating Income. This study adopted multiple regression analysis by using EViews 9.0 software. This study reveals that CLI has a positive and significant impact on ROA, which indicated that the expansion of business cycle activities would increase Islamic banks' profitability. Thus, this study suggests that Islamic bank should engage with the companies that relied on their business activities in the rill sector to boost their profitability. The limitation of this study is this study adopted Indonesian Islamic banks in general. Therefore, this study does not capture the correlation amongst the variables in the specific Islamic banks and region, which might be different from this result due to the differences in banks' internal conditions, culture, and the business cycle in the various region.
\end{abstract}

Keywords: Business cycle, composite leading indicator (CLI), profitability, Islamic bank

Received

December 27, 2020
Revised

March 25, 2021
Accepted

March 31, 2021
Published

March 31, 2021

\section{INTRODUCTION}

Indonesia's financial sector is one sector that has a vital role in promoting the national economy and the local economy (Fianto et al., 2018). One of the most rapid developments of Islamic financial institutions in Islamic banks (Juhro et al., 2020). This fact indicated by the immensely increasing Islamic bank offices in Indonesia. There is approximately 2556 Islamic banking office in December 2018 by the Islamic banking statistics from the FSA. Furthermore, Nasution (2020) declared that, based on the Chairman of OJK (Indonesia Financial Services Authority), there is a massive increase of Islamic banking accounts at the end of December 2017, which is measured by 560 new accounts. Meslier et al. (2019) explained that Islamic banks effectively increase economic growth by channeling the funds for the customers who avoid the financial transaction that is not based on Sharia Compliance. In the broader view, Imam \& Kpodar (2016) clarified that the principles of Sharia law rely on ethical values in all aspects of banking transactions, such as the prohibition of interest rate and based on the actual economic activities. Moreover, Fianto et al. (2019) affirmed that since Muslim need financial products which correspondent with their beliefs, Islamic institution is predicted to have a vital role in Indonesia. Thus, Indonesia, as the largest 
Muslim population country (Rahmah \& Armina, 2020), the contribution of Islamic banks on promoting the business cycle, is promoting (Abduh \& Azmi Omar, 2012). Based on these explanations, Islamic banks' performances become an essential topic to study to evaluate Islamic banks' contribution to national economic conditions.

There are several aspects in assessing the financial performance either by aspect earnings or profitability (Rizvi et al., 2019). Profitability, measured by return on assets (ROA), is defined as income generated from income after deducting all expenses incurred during a particular period (Sahyouni \& Wang, 2019). It is one of the essential factors representing the manager's success in allocating financial resources (Alarussi \& Alhaderi, 2018). Numerous study has been widely discussed about the affecting factors of Islamic banks profitability, such as (Khasawneh, 2016); (Sriyana, 2015); (Maamor et al., 2018); (Shahid et al., 2015); (Sayid et al., 2014); (Zarrouk et al., 2016); (Masood \& Ashraf, 2012); (Farook et al., 2012) and (Sudarsono, 2017). These studies portray that macroeconomics variables and internal-financial indicators play a significant role in shaping the profitability of Islamic banks. However, this current study tries to focus on the impact of the business cycle on the Islamic bank's profitability. Islamic banks have a strong correlation with real economic activities, which reflected by the profit and loss sharing contracts. Kayed (2012) explained that Islamic banking promotes the creation of a business cycle and SMEs through partnership financing or well-known as Profit-Loss Sharing (PLS).

Several indicators reflect the country's economic condition. One of them is the business cycle (Djennas, 2016). The business cycle plays an essential role in maintaining the stability of an economy because if the business cycle declines in an extended period, it will result in a growing unemployment rate, trigger-up the inflation level, which will harm the economy of a country (Kassim, 2016). Economists from the National Bureau of Economic Research (NBER) began to research and develop indicators that can be used to determine the movement of the business cycle (Stock \& Watson, 1993). Leading indicators are indicators that tend to change direction before the business cycle occurs or indicators used to predict a turning point in the business cycle (Nordstrom, 2007). Organization for Economic Cooperation and Development (OECD) has successfully issued the Composite Leading Indicator (CLI). CLI can be used as a signal the start of a turning point the business cycle that shows fluctuations in economic activity around its potential long-term level (OECD Data, 2016). Vervuurt (2016) revealed that the CLI is an adequate measure of the stages of the business cycle. In summary, the business cycle itself can be used to know the position of the economy of a country, by studying the business cycle of a country can avoid the economic recession that could lead to declining economies. Referring to the previous explication, we are trying to capture CLI and ROA connectedness, which represented in the following figure. 
Figure 1. Comparison between the growth of CLI and ROA

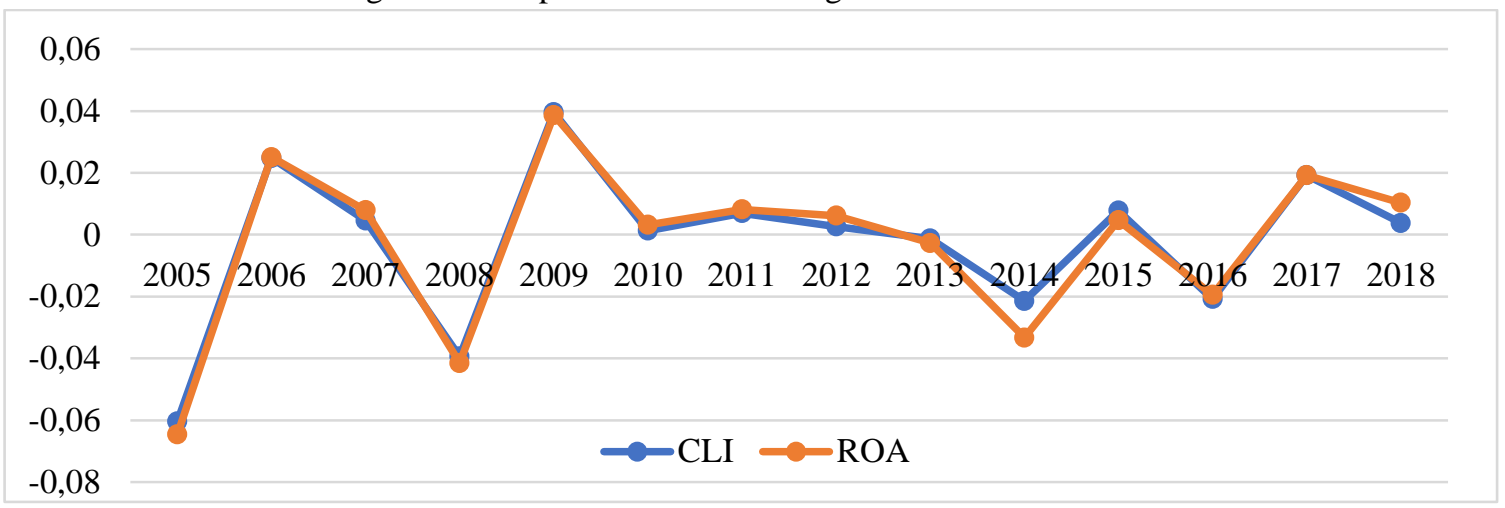

From Figure 1, we can affirm that CLI and ROA's growth appears to move in the same direction covering the period from 2005-2018. Precisely, in 2008 which is the global crisis period (Bank Indonesia, 2009) hit the CLI and ROA growth similarly. Furthermore, in 2009, the growth of CLI and ROA increase simultaneously. This figure indicates a strong connection between CLI and the profitability of the Islamic bank's sector. Based on the previous explanation and facts, this research is done to determine what factors affect Shia bank profitability in Indonesia. These factors consist of internal and external factors. This study's interest is to use variable composite leading indicators as a new variable compared to the previous studies.

\section{LITERATURE REVIEW Islamic Bank Profitability}

There are several aspects in assessing financial performance, one of which is earnings or profitability. The measure of profitability used is return on assets (ROA) (Sufian \& Habibullah, 2010). In general, profitability is defined as the company's revenue generated from revenue after deducting all costs incurred during a given period. This is one of the most important factors that signifies the success of shareholder management in providing satisfaction and attractiveness for investors and for sustainable companies (Alarussi \& Alhaderi, 2018). According to Sarwo (2017) profitability can be affected by FDR and BOPO variables. Whereas according to Wibowo \& Syaichu (2013) profitability can be affected by BOPO and CAR variables. Non-financial activities also allow sharia banks to get to more. Better performance from sharia banks can also be seen when GDP and investment are high (Zarrouk et al., 2016).

\section{Composite Leading Indicator}

In order to know and detect the repeated movement of cycles in this business cycle, economists from the National Bureau of Economic Research (NBER) began researching and developing indicators that can be used to determine the movement of the (Stock \& Watson, 1993). Leading Indicators are a collection of indicators that tend to change direction before the business cycle occurs or indicators used to predict turning points in the business cycle. The Organization for Economic Co-operation and Development (OECD) has successfully issued a Composite Leading Indicator (CLI) that can be used as an early signal of a turning 
point in the business cycle that shows fluctuations in economic activity around its long-term potential level. Vervuurt (2016) revealed that the CLI is an adequate measure of the business cycle stage.

\section{Research Accomplished}

Numerous studies have been examined the determining factors of the Islamic bank's profitability. Includes Zarrouk et al. (2016), this study investigates the affecting factors of Islamic banks and conventional bank's profitability in the Middle East and North Africa (MENA) covering the period from 1994-2012. This study adopted a panel data regression method and used 51 Islamic banks operating in the MENA region. The findings of this study are the profitability is positively influenced by the cost-effectiveness of the bank, asset quality, and capitalization levels. The results also show that non-financing activities allow Islamic banks to obtain higher profits. Furthermore, this study also confirmed that the inflation rate did not significantly influence Islamic banks' profitability. In the broader context Alharbi (2017) discusses the determinants of profitability of Islamic banks around the globe during the period from 1992-2008. Using unbalanced panel data, the results of this study showed that several variables, including the capital ratio and GDP per capita, have a positive effect on the profitability of Islamic banks.

Similarly, Yanikkaya et al. (2018) also conducted a study to determine the influenced factor of profitability by using 74 Islamic banks data in the Organization of Islamic Cooperation countries and the United Kingdom from 2007 to 2013. This study adopted dynamic panel data and found that inflation statistically has a significant and positive impact on Islamic bank's ROA. The result implied that the higher inflation rate would lead to an increasing in ROA. Besides, Maamor et al. (2018) also revealed that inflation and GDP are the most vital variables which shaped the ROA rate of Islamic bank in Brunei covering the period from 2012-2016. This study explained that the risen of the inflation rate would drive the Islamic bank to increase the product's price, which in turn trigger-up their revenue. Moreover, Khasawneh (2016) examined the driven factors of 61 Islamic banks in the MENA region, covering the period from 2006-2013. This study ascertained that income ratio, loan to total assets, and economic condition were simultaneously influencing the ROA of Islamic banks. Therefore, this study suggests that Islamic banks should improve their risk management and assessment ability to escalate their profit.

Chowdhury \& Rasid (2016) found that the profitability of 29 Islamic banks in GCC countries from 2005 to 2013 was affected by equity financing, efficiency ratio, and inflation. Additionally, Toumi (2019) adopted binary logistic regression to revealed the differences between Islamic and conventional banks in the Middle East region based on capital structure and profitability. This study used data observation from 2006-2014. This study described that profitability is a valid variable to distinguish Islamic banks from conventional banks. The affecting factors for the two banks are different. Moreover, this study also ascertained that the higher loan ratio, credit risk, and cost ratio would degrade the Islamic bank's profit. Additionally, Masood \& Ashraf (2012) researched using four regions as his sample of observations, including African countries, Asian countries, Middle East countries, and South Asian countries during the period from 2006-2010. This study confirmed that the ROA ratio 
of 25 Islamic banks affected by the asset size, non-performing finance, capital adequacy, and GDP.

Trabelsi \& Trad (2017) discovered that bank capital is the main factor in forming Islamic banks' profitability in 18 countries, including Indonesia, during the period from 20062013. Furthermore, this study also ascertained that in Southeast Asia, inflation significantly reduces the credit risk level of Islamic banks and, consequently, intensifies the profitability level. Besides, Azad et al. (2020) found that bank fee play as the main factor affecting the Islamic banks' profitability in 20 countries for the period from 2000-2015. In the context of Malaysian Islamic banks, Ramlan \& Adnan (2016) discovered that there is a significant relationship between ROA and total equity to the total asset of Islamic banks. Moreover, Paltrinieri et al. (2020) demonstrated that non-interest income is positively associated with the profitability of Islamic banks. This study used 47 Islamic banks in selected OIC countries during the period from 2007-2016. From the result of this study, we can clarify that Islamic banks' internal financial performances positively impact the banks' revenue. Similarly, Trad et al. (2017) conducted research covering 78 Islamic banks in 12 countries for the 2004-2013 period. This study affirmed that the capital of Islamic banks is the primary factor that shaped the profitability rate.

Additionally, limited previous studies have been examined the correlation between the business cycle and banks' profitability, especially in the context of Islamic banks. Slimi (2012) confirmed that in selected MENA commercial banks throughout 1990-2007, there is no empirical evidence concerning the connectedness between the business cycle and banks' profitability. However, this study hypothesis that business cycle fluctuations substantially affect the profitability of banking institutions. In contrast, Albertazzi \& Gambacorta (2009) ascertained that the business cycle measured by GDP significantly affected the banks' profitability in euro-area countries. This study explained that during the financial crisis, which indicates the degrading of GDP level would trigger-down the banks' profitability. The result of this study also supported by Apergis's (2009) research result, which discovered that the banks' profitability in Greek banks has a procyclical correlation with the business cycle covering the period from 1990-2006.

Extensive previous research mainly discussed the internal factors of Islamic banks and several macroeconomics variables to determine banks' profitability. However, the study focused on the correlation between the Islamic bank's profitability, and the business cycle is still limited. However, numerous studies have been proved that Islamic bank has strong connectedness with real economic activities. Thus, this study uses a differentiator variable, composite leading indicators, where the Composite Leading Indicator (CLI) variable is a variable used to measure the business cycle. CLI as a proxy of the business cycle. Therefore, the result of this study would enhance and fill the gap of literature review. In particular, this research will dwell on the questions about the impact of Composite Leading Indicator (CLI), Islamic banks' performance, and macroeconomic variables towards the profitability of Islamic banks in Indonesia. Thus, the schematic diagram of this study is presents in figure 2. 
Figure 2: Schematic Diagram of the Study

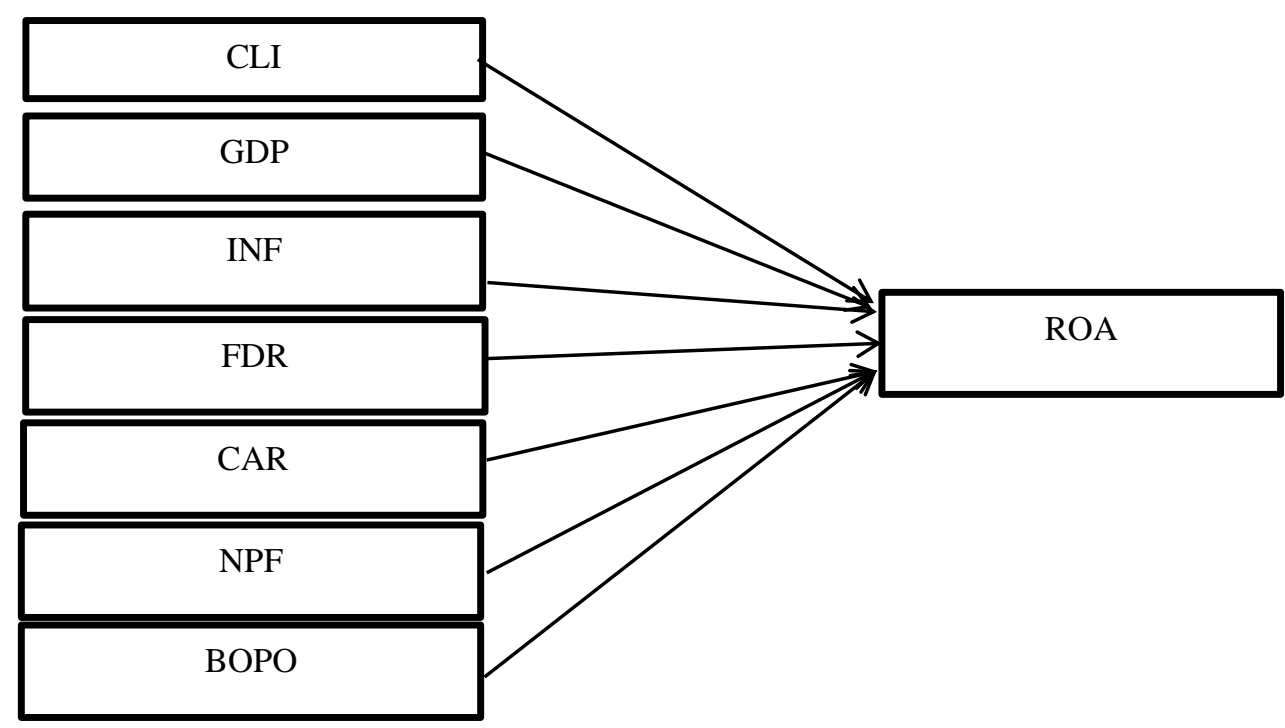

\section{METHOD}

This study empirically evaluating the contribution of Islamic banks towards economic growth in Indonesia after the global economic crisis by utilizing quarterly data from 2004 to 2018. The selection of sample period is based on the data availability, moreover, this study aims to covering the crises period in order to ascertained the contribution of business cycle towards Islamic banks' profitability ratio during economic turmoil. Therefore, this study covering the subprime-mortgage in 2008, the Greek crisis in 2010, and the depreciation of IDR against USD in 2018 (Bank Indonesia, 2018; Setya et al., 2020).

This study adopts Multiple linear regression to evaluate the correlation between Islamic banks' profitability and business cycle. Hesamian \& Akbari (2020) explained that Multiple regression analysis could be defined as the regression model with one dependent variable and more than one independent variable. Thus, this method allows the researchers to encourage several predictors variables in an equation to understand their correlation with the dependent variable (Alexopoulos, 2010). Uyanık \& Güler (2013) stated that Multiple regression analysis is more suitable for causal (ceteris paribus) analysis. Multiple linear regression methods is one of the most widely used of all statistical methods. In banking and finance literature, regression analysis is a very common method used to find the determinants of bank performance (Amzal, 2016). Besides, Trad et al., (2017) adopted a multiple regression analysis methods to check the robustness of the result in determining the financial stability of Islamic banking. This study utilized Econometric Views (EViews) 9.0 software to processed the data. The general model is formulated by equation (1):

$$
\mathrm{ROA}=\alpha+\beta_{1} \mathrm{CLI}_{\mathrm{t}}+\beta_{2} \mathrm{GDP}_{\mathrm{t}}+\beta_{3} \mathrm{INF}_{\mathrm{t}}+\beta_{4} \mathrm{FDR}_{\mathrm{t}}+\beta_{5} \mathrm{CAR}_{\mathrm{t}}+\beta_{6} \mathrm{NPF}_{\mathrm{t}}+\beta_{7} \mathrm{BOPO}_{\mathrm{t}}+\mu_{\mathrm{t}}
$$

From the above formulated model, we can confirm that this study applied ROA for the dependent variable and CLI to measures the business cycles. Whereas for the six variables is used as the control variables which selected based on numerous empirical 
researches finding that has been explained in literature review and hypothesis development section. In details, definitions of the variables used in this study are described as follows:

Table 1. Variable Explanation

\begin{tabular}{|c|c|c|}
\hline Name & Definition & Sources \\
\hline $\begin{array}{l}\text { Return on Assets } \\
\text { (ROA) }\end{array}$ & $\begin{array}{l}\text { Return on Assets (ROA) is a ratio used to measure a } \\
\text { bank's ability to generate profits. }\end{array}$ & $\begin{array}{l}\text { (Otoritas Jasa Keuangan, } \\
\text { 2020) }\end{array}$ \\
\hline $\begin{array}{l}\text { Composite Leading } \\
\text { Indicators (CLI) }\end{array}$ & $\begin{array}{l}\text { Composite Leading Indicator (CLI) is an index that } \\
\text { describes the movement output gap }\end{array}$ & (OECD Data, 2020) \\
\hline $\begin{array}{ll}\text { GDP } & \text { GROWTH } \\
(\text { GDP }) & \end{array}$ & $\begin{array}{l}\text { GDP GROWTH is a measure of the economic } \\
\text { development of the country and until how far the } \\
\text { economy of the country has grown or is shrinking. }\end{array}$ & (ISDB Data, 2018) \\
\hline Inflation (INF) & $\begin{array}{l}\text { Inflation is a general rise in the prices of goods and } \\
\text { services during a specific time. }\end{array}$ & (Bank Indonesia, 2020) \\
\hline $\begin{array}{l}\text { Financing to Deposit } \\
\text { Ratio (FDR) }\end{array}$ & $\begin{array}{l}\text { Financing to Deposit Ratio (FDR) is financing and } \\
\text { third-party funds. }\end{array}$ & $\begin{array}{l}\text { (Otoritas Jasa Keuangan, } \\
\text { 2020) }\end{array}$ \\
\hline $\begin{array}{l}\text { Capital Adequacy } \\
\text { Ratio (CAR) }\end{array}$ & $\begin{array}{l}\text { Capital Adequacy Ratio (CAR) is the capital and risk- } \\
\text { weighted assets. }\end{array}$ & \\
\hline $\begin{array}{l}\text { Non-Performing } \\
\text { Financing (NPF) }\end{array}$ & $\begin{array}{l}\text { Non-Performing Financing (NPF) Problem of } \\
\text { financing problems of substandard up to a total } \\
\text { standstill and financing. }\end{array}$ & \\
\hline $\begin{array}{lr}\text { Operating } & \text { Costs } \\
\text { Operating } & \text { Income } \\
(\mathrm{BOPO}) & \end{array}$ & $\begin{array}{l}\text { Operating Costs Operating Income (BOPO) are } \\
\text { operating expenses and operating income. }\end{array}$ & \\
\hline
\end{tabular}

\section{RESULT}

The multiple linear regression should be done after meeting several requirements of classical assumption. There are several stages in the test of classical assumptions. Includes, autocorrelation, multicollinearity, heteroscedasticity, and normality test. Here are the autocorrelation test results as follows:

Autocorrelation test is used to determine the presence of the correlation that occurs between the residual on one observation with other observations on the regression model.

Table 2. Autocorrelation Test

\begin{tabular}{|l|l|l|}
\hline F-statistic & 1.382963 Prob. F (2,5) & 0.3326 \\
\hline Obs * R-squared & 5.342427 Prob. Chi-Square (2) & 0.0692 \\
\hline
\end{tabular}

This regression model used the Breusch-Godfrey analysis to assess the absence of autocorrelation. Chi-Square is used to determine the presence of autocorrelation on the model used. From the Breusch-Godfrey test, it has been made evident that the value of Prob. ChiSquare is 0.0692 , higher than in 0.05 . Thus, it can be concluded that the regression model to be used passes the autocorrelation test.

Heteroscedasticity test is used to detect the condition of independent variable is highly correlated with the independent variables which included in the multiple regression test. 
Table 3. Heteroscedasticity Test

\begin{tabular}{|l|c|l|}
\hline F-statistic & 0.284374 Prob. F (7,7) & 0.9404 \\
\hline Obs * R-squared & 3.321160 Prob. Chi-Square (7) & 0.8538 \\
\hline Scaled explained SS 1.023405 Prob. Chi-Square (7) & 0.9944 \\
\hline
\end{tabular}

Based on table 3, we can confirm that the value of the chi-square probability is 0.8538, which means higher than 0.05. Then this regression model meets the heteroscedasticity test.

Normality test is a test used to see whether data to be used is a normal distribution. In this study, test normality using the assessment of Jarque-Bera Probability.

Figure 3. Normality Test

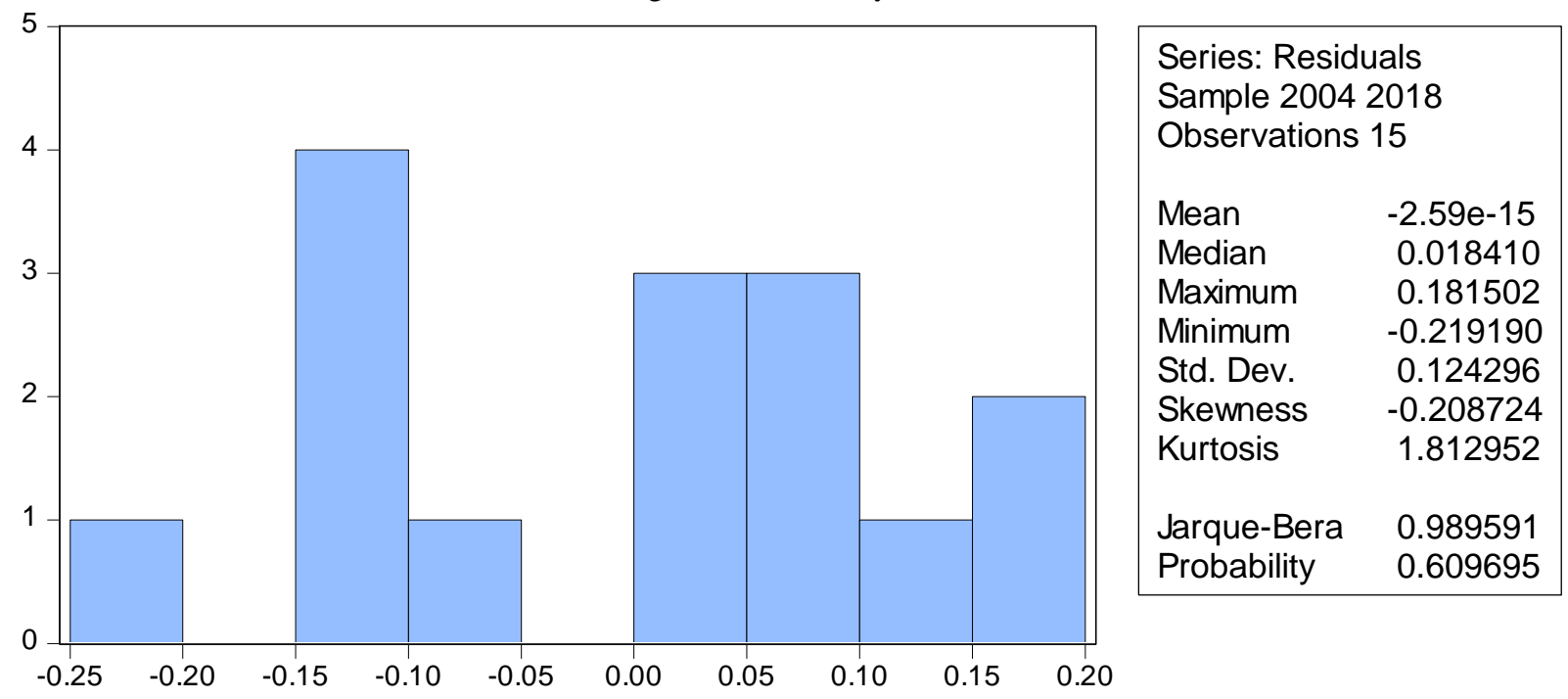

The normal distribution of the data to reflected by the value of probability higher than at 0.05 . Based on figure 3 , the probability value is 0.609695 , which means higher than 0.05 . This result implied that the data is said to be normally distributed.

A multicollinearity test is used to determine the linear relationship between the independent variables in the regression model. 
Table 4. Multicollinearity Test

\begin{tabular}{|c|c|c|c|}
\hline & Coefficient & Uncentered & Centered \\
\hline Variable & Variance & VIF & VIF \\
\hline C & 25.11320 & 12191.37 & NA \\
\hline NPF & 0.006112 & 39.49114 & 3.280187 \\
\hline INF & 0.000438 & 11.56222 & 2.950787 \\
\hline GDP & 0.014796 & 229.9288 & 3.609167 \\
\hline FDR & $3.95 E-05$ & 177.7624 & 2.804346 \\
\hline CLI & 0.001940 & 9414.337 & 2.770370 \\
\hline CAR & 0.000737 & 77.22065 & 2.540931 \\
\hline BOPO & $7.67 \mathrm{E}-05$ & 264.9814 & 4.318800 \\
\hline
\end{tabular}

Based on table 4, the value of the VIF of all variables under 10.00. Therefore, it can be concluded that this model does not occur multicollinearity.

\section{Multiple Regression Test}

Referring to the table 2-4, we can affirm that the model is passed all the classical assumptions. Thus, the following table represents the multiple regression result of the model: 
Table 5. Multiple Regression Test

\begin{tabular}{|c|c|c|c|c|}
\hline Variable & Coefficient & Std. Error & t-Statistic & Prob. \\
\hline $\mathrm{C}$ & -6.024337 & 5.011308 & -1.202149 & 0.2684 \\
\hline CLI & 0.099905 & 0.044047 & 2.268153 & 0.0576 \\
\hline GDP & 0.136502 & 0.121637 & 1.122208 & 0.2988 \\
\hline INF & -0.027075 & 0.020933 & -1.293453 & 0.2369 \\
\hline FDR & 0.000766 & 0.006282 & 0.121957 & 0.9064 \\
\hline CAR & -0.053491 & 0.027153 & -1.969985 & 0.0895 \\
\hline NPF & -0.299424 & 0.078182 & -3.829849 & 0.0065 \\
\hline BOPO & -0.016884 & 0.008760 & -1.927448 & 0.0953 \\
\hline R-squared & 0.944626 & \multicolumn{2}{|c|}{ Mean dependent var } & 1.398667 \\
\hline Adjusted R-squared & 0.889251 & \multicolumn{2}{|c|}{ S.D. dependent var } & 0.528203 \\
\hline S.E. of regression & 0.175780 & \multicolumn{2}{|c|}{ Akaike info criterion } & -0.334636 \\
\hline Sum squared resid & 0.216291 & \multicolumn{2}{|c|}{ Schwarz criterion } & 0.042991 \\
\hline Log likelihood & 10.50977 & \multicolumn{2}{|c|}{ Hannan-Quinn criter. } & -0.338658 \\
\hline F-statistic & 17.05885 & \multicolumn{2}{|c|}{ Durbin-Watson stat } & 1.923247 \\
\hline Prob(F-statistic) & 0.000667 & & & \\
\hline
\end{tabular}

Multiple linear regression is an analysis used to determine the influence of two or more independent variables (CLI, INF, GDP, CAR, FDR, NPF, and BOPO) against dependent variables (ROA). The impact of the use of multiple regression analyses can be used to break up or decrease the value of dependent variables, which can be done through raising or lowering the state of the variable Independent. Based on a statistical test multiple regression that has been conducted can be compiled mathematical equations of this research as follows:

$$
\begin{gathered}
\mathrm{ROA}=-6.024337+0.099905 \mathrm{CLI}+0.136502 \mathrm{GDP}-0.027075 \mathrm{INF}-0.053491 \mathrm{CAR}+ \\
0.000766 \mathrm{FDR}-0.299424 \mathrm{NPF}-0.016884 \mathrm{BOPO}+\mathrm{e}
\end{gathered}
$$

The above statistical test results portrayed that composite leading indicator, capital adequacy ratio, non-performing financing, and operating cost of operating income were significantly affecting the profitability ratio of Islamic banking. However, gross domestic product, inflation, and finance to deposit ratio do not have an essential role in forming the Islamic banks' profitability in Indonesia. From table 4, we can confirm that the business cycle represented by CLI has a positive and significant impact on Islamic bank's profitability. The probability value can show this is lower than $\alpha 10 \%(0.0576<0.1)$. 


\section{DISCUSSION}

The result of this study implies that the increase in the business cycle would lead to higher Islamic banks' profitability. This result supported by several previous research in the context of conventional banks such as Albertazzi \& Gambacorta (2009) and Apergis (2009). Those studies explained that business activities indicate the total output produced by companies, thus measuring the economic condition. The conducive business environment would trigger-up the financial intermediaries' institution, such as Islamic banks, to allocate the capital resources and earn higher profit. Specifically, Islamic banks rely on the real sector of economic activities (Ben Mimoun, 2019). Thus, the connectedness between the business cycle and Islamic banks will be stronger than conventional counterparts.

Moreover, a previous study conducted by Kayed (2012) explained that Islamic banking promotes the creation of SMEs through partnership financing or well-known as Profit-Loss Sharing (PLS). PLS means Islamic banks and entrepreneurs sharing risks, as well as rewards related to entrepreneurial activities, which, in turn, will bring the economy to new heights. Besides, Risfandy et al. (2020) also explained that profit and loss sharing (PLS) mechanisms are more attractive for entrepreneurs because it based on equity financing and not a debt arrangement as in conventional banks, which more beneficial for both parties. Similarly, Fianto et al. (2018) and Naqvi et al. (2018) stated that PLS contract is the equity financing which differentiates Islamic finance institution from the conventional interest-based system. Hence, this current study underlined that companies should engage more in Islamic banks to obtain their financial resources. It is offering more benefit for companies than conventional banks. As a result, the increase of the company's business cycle and performance would move in the same direction with the Islamic banks' profitability.

In the other perspective, Mensi et al. (2020) explained that the presence of Islamic banks would provide financial services for those who are willing to use banking services under Islamic principles. As Pratiwi (2016) said, partnership contracts in Islamic banks are allowed SMEs to present better performances by channelizing the supportive technology and knowledge for SMEs. Besides, evidence from 280 banks in 20 countries, Nosheen \& Rashid (2019) portrayed that Islamic banks have qualified and higher financial to deposit ratio than conventional counterparts. Islamic banks have a better performance because it is focused on investment in real assets, non-aggressive lending and provisioning strategies (Nosheen \& Rashid, 2019). Therefore, this study affirmed that Islamic banks' more financial intermediaries, the higher profitability than Islamic banks. Thus, this study corroborates the previous literature by ascertaining that the increase of business that expands their business scales by gaining financial support from Islamic banks would affect Islamic banks' profitability.

This study also discovered that the capital adequacy ratio has a statistically significant and negative effect on the profitability of Islamic banks. This reflected by the probability value is lower than $\alpha 10 \%(0.0895<0.1)$. This result is in line with the existing study ALOmar \& Al-Mutairi (2008); thus, the study suggested that Islamic banks should boost their capital adequacy ratio to improve their capability to distribute the potential project funding. 
In the context of Indonesian Islamic banks, Sriyana (2015) discovered that the capital adequacy ratio is negatively impacting the ROA. This study explained that the management risk perspective could explain the negative relationship between those variables. Islamic banks' contracts rely on real economic activities, for instance, profit-loss sharing contracts. The higher the capital ratio of Islamic banks, the greater capacity of Islamic banks to cover the assets losses from the consumers' business activities. Consequently, the higher capital tends to degrade the Islamic banks' profitability ratio.

In contrast, Masood \& Ashraf (2012) and Masood et al. (2015) revealed that assets size has positive and significant impact on the profitability of Islamic banks. Moreover, Trabelsi \& Trad (2017) also found that the higher liquidity of Islamic banks reflects the higher ability of banks' to manage and reduce their credit risk. The logic behind the result of this current study might be the limited capital resources and liquidity restricted the banks' competences to raise their revenue through financing the business activities.

Furthermore, non-performing finance is found to have a negative impact on Islamic banks' profitability, represented by the ROA rate. The probability value is 0.0065 and lower than $\alpha 1 \%$. This study indicates that the decrease of NPF will enhance the banks to earn more profit. Previous research conducted by Masood \& Ashraf (2012), Sriyana (2015) and Shah Khan et al. (2014) discovered that NPF affects significant negative profitability, which means that when there is a hike in the NPF hence the profitability value of Islamic banks will decline. The ratio of non-performing loans which are comprised of loans classified as substandard, doubtful, and loss. NPF is credited that they are not performing well and are classified as inferior, uncertain, and failure. The task of Bank Indonesia (BI), among others, is to maintain and preserve a healthy banking system and can be trusted to keep the economy. Therefore, as central banks and banking supervisors in Indonesia, BI provides the size of the Bank rating provisions. One of the requirements of the NPF is BI Banks NPF must have less than 5\%. In contrast, Supriani \& Sudarsono (2018) showed no significant relationship between ROA and NPF in Islamic banks.

Besides, this study demonstrated that the operating cost of operating income (BOPO) negatively affected the Islamic banks' profitability. Moreover, the probability value is lower than $\alpha 10 \%(0.0953<0.1)$, indicating that BOPO has an essential role in shaping the ROA level of Indonesian Islamic banks Sukmana \& Febriyati (2016) explained that the smaller ratio of BOPO, the more efficient Islamic banks manage their operational cost, which, in turn, improves the banks' financial performances. Therefore, in this current study, the negative sign of coefficient reflects that the most efficient Islamic banks in managing their operational cost would lead the profitability to move to a higher level. Several studies such a Sriyana (2015), Masood et al. (2015) and Chowdhury \& Rasid (2016) also verified that BOPO significantly negatively affects the profitability of Islamic banks.

Table 5 also describes that several variables, such as gross domestic product, inflation, and financing to deposit ratio, were not statistically significant in influencing the Indonesian Islamic banks' profitability. This study ascertained that Inflation has insignificant impact on Islamic banks' profitability. This result, supported by the previous study conducted by Sholikhin et al., (2020), also showed that Inflation has no significant impact on the profitability of Islamic banks. The probability value of these variables can show this result are higher than $\alpha 10 \%(0.2988,0.2369$, and $0.9064>0.1)$. This study ascertained that GDP 
has a positive but insignificant impact on Islamic banks' profitability. This result, supported by the previous study conducted by Masood et al. (2015), also showed that GDP has no significant impact on the profitability of Islamic banks. In contrast, Shahid et al. (2015) found that GDP has a positive and significant effect on the profitability of Islamic banks in Pakistan. Similarly, Al-Harbi (2020) also declared that GDP and the profitability of Islamic bank in Iran and Sudan are moves in the same direction. Specifically, in Indonesia's context, Rahmah \& Armina (2020) revealed that GDP has a positive impact on the banks' profitability. These studies explained that the increase in GDP measured improving the quantity of production, consumption, and expenditure. As a result, the financial transaction would rise. Therefore, as a financial institution, Islamic banks would have more opportunity to gain a higher profit.

The result of this study also discovered that inflation has negative but does not have a substantial impact on ROA. Existing studies include Zarrouk et al. (2016) and Trad et al. (2017) stated that inflation does not play a significant role in driving the Islamic banks' profitability. In contrast, several previous studies such as Trabelsi \& Trad (2017) and Chowdhury \& Rasid (2016) proved that inflation significantly triggers down the profitability rate of Islamic banks. However, Shahid et al. (2015) demonstrated a positive and significant correlation between inflation and ROA. Furthermore, this current study discovered that financing to deposit ratio was not the essential variable that formed the Indonesian Islamic banks' profitability. This result supports the conclusion from the research by Alarussi \& Alhaderi (2018) which explained that the FDR has no significant effect on the banking profitability in Malaysia. In contrast, Sriyana (2015), Alzoubi (2018) and Sudarsono (2017) stated that FDR statistically affecting the Islamic banks' profitability ratio.

Furthermore, from the same table, we can verify that R-Squared for the model is 0.889251 . This value reflected that about $88.9 \%$ of changes in the percentage of Indonesian Islamic banks' profitability are explained by CLI, GDP, inflation, CAR, FDR, NPF, and BOPO during the period from 2004-2018. Besides, we can find that Prob (F-Statistic) is 0.000667 with confidence level at $\alpha 5 \%$; the F-statistic test in this current study reveals probability value is higher than 0.05. This value implied that CLI, GDP, inflation, CAR, FDR, NPF, and BOPO simultaneously were the determinants factors of Islamic banks' profitability ratio, which measured by ROA.

\section{CONCLUSION}

The statistical data analysis in this study explains that the composite leading indicator variables have a positive influence on the profitability of Islamic banks. This study revealed that the increase in business cycle activities would boost the Islamic banks' profitability. Theoretically, the increase in the business cycle reflected the growing revenues of the company. Consequently, this phenomenon would affect the companies' ability to pay their loan to an Islamic bank and influence the increase of Islamic banks' profitability. Moreover, CAR, BOPO, and NPF variables negatively affect the profitability of Islamic banks. Furthermore, this study also demonstrated that INF, GDP, and FDR variables did not affect the profitability of Islamic banks in Indonesia. But collectively, the variables of CLI, CAR, BOPO, NPF, INF, GDP, and FDR are influential in the profitability of Islamic banks in 
Indonesia. Based on the result, this study suggests that the business cycle should offer financing more from Islamic banks. Moreover, the Islamic banks should enlarge their contribution towards the business cycle development, which, finally, will affect the increase of the Islamic banks' profitability itself. This study's main limitation is to examine and discuss the general correlation between Islamic banks and the business cycle in Indonesia; thus, the result might be biased when it turns to the specific Islamic banks, region and culture. Therefore, further research is needed to deepening this topic by adopting panel data regression to illustrate the particular Islamic banks' condition and business cycle in various areas.

\section{REFERENCES}

Abduh, M., \& Azmi Omar, M. (2012). Islamic banking and economic growth: the Indonesian experience. International Journal of Islamic and Middle Eastern Finance and Management, 5(1), 35-47. https://doi.org/10.1108/17538391211216811

Al-Harbi, A. (2020). Banks' Profitability in an Islamized Financial System: Comparative Study between Iran and Sudan. International Journal of Islamic Banking and Finance Research, 4(1), 8-14. https://doi.org/10.46281/ijibfr.v4i1.498

AL-Omar, H., \& Al-Mutairi, A. (2008). Bank-Specific Determinants of Profitability: The case of Kuwait. Journal of Economic \& Administrative Sciences, 24(2), 20-34.

Alarussi, A. S., \& Alhaderi, S. M. (2018). Factors affecting profitability in Malaysia. Journal of Economic Studies, 45(3), 442-458. https://doi.org/10.1108/JES-05-2017-0124

Albertazzi, U., \& Gambacorta, L. (2009). Bank profitability and the business cycle. Journal of Financial Stability, 5(4), 393-409. https://doi.org/10.1016/j.jfs.2008.10.002

Alexopoulos, E. C. (2010). Introduction to multivariate regression analysis. Hippokratia, 14(December 2010), 23-28.

Alharbi, A. T. (2017). Determinants of Islamic banks' profitability: international evidence. International Journal of Islamic and Middle Eastern Finance and Management, 10(1), 331-350. https://doi.org/10.1108/IMEFM-12-2015-0161

Ali, Q., Maamor, S., Yaacob, H., \& Gill, M. U. T. (2018). Impact of Macroeconomic Variables on Islamic Banks Profitability. Journal of Accounting and Applied Business Research, 1(2), 1-16.

Alzoubi, T. (2018). Determinants of bank profitability: Islamic versus conventional banks. Banks and Bank Systems, 13(3), 106-113. https://doi.org/10.21511/bbs.13(3).2018.10

Amzal, C. (2016). the Impact of Macroeconomi Variables on Indonesia Islamic Banks Profitability. Jurnal Ekonomi Dan Bisnis Islam, 2(1), 71-86.

Apergis, N. (2009). Bank profitability over different business cycles regimes: Evidence from panel threshold models. Banks and Bank Systems, 4(3), 59-70. https://doi.org/10.2139/ssrn.992654

Azad, A. S. M. S., Azmat, S., \& Hayat, A. (2020). What determines the profitability of Islamic banks: Lending or fee? International Review of Economics and Finance, May. https://doi.org/10.1016/j.iref.2019.05.015

Bank Indonesia. (2018). Monetary Policy Report Quarter I 2018.

Bank Indonesia. (2020). Inflation Report.

Ben Mimoun, M. (2019). Islamic banking and real performances in a dual banking system. International Journal of Islamic and Middle Eastern Finance and Management. https://doi.org/10.1108/imefm-07-2018-0223

Chowdhury, M. A. F., \& Rasid, M. E. S. M. (2016). Determinants of Performance of Islamic Banks in GCC Countries: Dynamic GMM Approach. In Advances in Islamic Finance, 
Marketing, and Management. https://doi.org/10.1108/978-1-78635-899-820161005

Djennas, M. (2016). Business cycle volatility, growth and financial openness: Does Islamic finance make any difference? Borsa Istanbul Review, 16(3), 121-145. https://doi.org/10.1016/j.bir.2016.06.003

Farook, S., Hassan, M. K., \& Clinch, G. (2012). Profit distribution management by Islamic banks: An empirical investigation. Quarterly Review of Economics and Finance, 52(3), 333-347. https://doi.org/10.1016/j.qref.2012.04.007

Fianto, B. A., Gan, C., Hu, B., \& Roudaki, J. (2018). Equity financing and debt-based financing: Evidence from Islamic microfinance institutions in Indonesia. Pacific-Basin Finance Journal, 52(August 2016), 163-172. https://doi.org/10.1016/j.pacfin.2017.09.010

Fianto, B. A., Maulida, H., \& Laila, N. (2019). Determining factors of non-performing financing in Islamic microfinance institutions. Heliyon, 5(8). https://doi.org/10.1016/j.heliyon.2019.e02301

Hesamian, G., \& Akbari, M. G. (2020). A robust varying coefficient approach to fuzzy multiple regression model. Journal of Computational and Applied Mathematics, 371, 113. https://doi.org/10.1016/j.cam.2019.112704

Imam, P., \& Kpodar, K. (2016). Islamic banking: Good for growth? Economic Modelling, 59, 387-401. https://doi.org/10.1016/j.econmod.2016.08.004

ISDB Data. (2018). IDB Member Country Macro-Economic Statistics.

Juhro, S. M., Narayan, P. K., Iyke, B. N., \& Trisnanto, B. (2020). Is there a role for Islamic finance and R\&D in endogenous growth models in the case of Indonesia? Pacific Basin Finance Journal, 101297. https://doi.org/10.1016/j.pacfin.2020.101297

Kassim, S. (2016). Islamic finance and economic growth: The Malaysian experience. Global Finance Journal, 30, 66-76. https://doi.org/10.1016/j.gfj.2015.11.007

Kayed, R. N. (2012). The entrepreneurial role of profit-and-loss sharing modes of finance: theory and practice. International Journal of Islamic and Middle Eastern Finance and Management, 5(3), 203-228. https://doi.org/10.1108/17538391211255205

Khasawneh, A. Y. (2016). Vulnerability and profitability of MENA banking system: Islamic versus commercial banks. International Journal of Islamic and Middle Eastern Finance and Management, 9(4), 454-473. https://doi.org/10.1108/IMEFM-09-2015-0106

Maamor, S., Yaacob, H., \& Gill, M. U. T. (2018). Impact of Macroeconomic Variables on Islamic Banks Profitability Impact of Macroeconomic Variables on Islamic Banks Profitability Biographical notes : Journal of Accounting and Applied Business Research, 1(April).

Masood, O., \& Ashraf, M. (2012). Bank-specific and macroeconomic profitability determinants of Islamic banks: The case of different countries. Qualitative Research in Financial Markets, 4(2-3), 255-268. https://doi.org/10.1108/17554171211252565

Masood, O., Ashraf, M., \& Turen, S. (2015). Bank-Specific and Macroeconomic Determinants of Bank Profitability: Evidence from Member States of the OIC. Journal of Islamic Financial Studies, 1(1), 43-51.

Mensi, W., Hammoudeh, S., Tiwari, A. K., \& Al-Yahyaee, K. H. (2020). Impact of Islamic banking development and major macroeconomic variables on economic growth for Islamic countries: Evidence from panel smooth transition models. Economic Systems, 44(1). https://doi.org/10.1016/j.ecosys.2019.100739

Meslier, C., Risfandy, T., \& Tarazi, A. (2019). Islamic banks' equity financing, Shariah supervisory board, and banking environments. Pacific-Basin Finance Journal. https://doi.org/10.1016/j.carbpol.2020.115849

Naqvi, B., Rizvi, S. K. A., Uqaili, H. A., \& Chaudhry, S. M. (2018). What enables Islamic banks to contribute in global financial reintermediation? Pacific Basin Finance Journal, 
52, 5-25. https://doi.org/10.1016/j.pacfin.2017.12.001

Nasution, Z. (2020). Profit efficiency development of Islamic Banking using the stochastic frontier approach. Jurnal Ekonomi \& Keuangan Islam, 6(1), 55-63. https://doi.org/10.20885/jeki.vol6.iss1.art6

Nordstrom, G. D. (2007). Leading indicators. Industrial Fabric Products Review, 92(11), 8. https://doi.org/10.1016/b978-0-12-295180-0.50026-4

Nosheen, \& Rashid, A. (2019). Business orientation, efficiency, and credit quality across business cycle: Islamic versus conventional banking. Are there any lessons for Europe and Baltic States? Baltic Journal of Economics, 19(1), 105-135. https://doi.org/10.1080/1406099X.2018.1560947

OECD Data. (2016). Composite leading indicator (CLI).

OECD Data. (2020). Selected indicators for Indonesia.

Otoritas Jasa Keuangan. (2020). Sharia Banking Statistic.

Paltrinieri, A., Dreassi, A., Rossi, S., \& Khan, A. (2020). Risk-adjusted pro fi tability and stability of Islamic and conventional banks : Does revenue diversi fi cation matter? July 2018. https://doi.org/10.1016/j.gfj.2020.100517

Pratiwi, A. (2016). Islamic banking contribution in sustainable socioeconomic development in Indonesia: An epistemological approach. Humanomics, 32(2), 98-120. https://doi.org/10.1108/H-12-2015-0085

Rahmah, A. Z., \& Armina, S. H. (2020). Macro and micro determinants of the nonperforming finance: The case of Indonesian Islamic bank. Jurnal Ekonomi \& Keuangan Islam, 6(1), 34-41. https://doi.org/10.20885/jeki.vol6.iss1.art4

Ramlan, H., \& Adnan, M. S. (2016). The Profitability of Islamic and Conventional Bank: Case Study in Malaysia. Procedia Economics and Finance, 35(October 2015), 359-367. https://doi.org/10.1016/s2212-5671(16)00044-7

Risfandy, T., Harahap, B., Hakim, A. R., Sutaryo, S., Nugroho, L. I., \& Trinugroho, I. (2020). Equity Financing at Islamic Banks: Do Competition and Bank Fundamentals Matter? Emerging Markets Finance and Trade, 56(2), 314-328. https://doi.org/10.1080/1540496X.2018.1553160

Rizvi, S. A. R., Narayan, P. K., Sakti, A., \& Syarifuddin, F. (2019). Role of Islamic banks in Indonesian banking industry: an empirical exploration. Pacific Basin Finance Journal, February, 101117. https://doi.org/10.1016/j.pacfin.2019.02.002

Sahyouni, A., \& Wang, M. (2019). Liquidity creation and bank performance: evidence from MENA. ISRA International Journal of Islamic Finance, 11(1), 27-45. https://doi.org/10.1108/IJIF-01-2018-0009

Sarwo, E. A. (2017). Determinan Profitabilitas Perbankan Syariah di Indonesia Periode Tahun 2007 - 2015. Universitas Airlangga.

Sayid, O., Musse, H., \& Echchabi, A. (2014). Factors Determining Islamic Banks 'Deposits in Qatar : An Empirical Study. 4(6), 987-994.

Setya, V. A., Supriani, I., \& Fianto, B. A. (2020). Determinants of Underpricing in Islamic and Non-Islamic Shares on IPO. Shirkah Journal of Economics and Business, 5(1). https://doi.org/10.22515/shirkah.v5i1.276

Shah Khan, M. M., Ejaz, F., \& Aslam, E. (2014). Determinants of Profitability of Islamic Banking Industry: An Evidence from Pakistan. Business \& Economic Review, 6(2), 2746. https://doi.org/10.22547/ber/6.2.2

Shahid, M. S., Hassan, M., \& Rizwan, M. (2015). Determinants of Islamic Banks' Profitability: Some Evidence from Pakistan. Pakistan Journal of Islamic Research, 16, 149-168.

Sholikhin, M. Y., Amijaya, R. N. F., \& Herianingrum, S. (2020). THE EFFECT OF SUKUK AND INFLATION ON THE PROFITABILITY OF ISLAMIC BANK IN INDONESIA. 
IJIBE (International Journal of Islamic Business Ethics), 5(1), 33-46.

Slimi, S. (2012). Bank profitability and the business cycle: Evidence from MENA countries. Economic Research Forum. https://doi.org/10.1016/j.jfs.2008.10.002

Sriyana, J. (2015). Islamic banks' profitability amid the competitive financing in Indonesia. International Journal of Applied Business and Economic Research, 13(4), 1695-1710.

Stock, J. H., \& Watson, M. W. (1993). Business Cycles, Indicators, and Forecasting. The University of Chicago Press.

Sudarsono, H. (2017). Analisis Pengaruh Kinerja Keuangan terhadap Profitabilitas Bank Syariah di Indonesia Pendahuluan Return on Aset ( ROA ) atau profitabilitas merupakan rasio yang digunakan. 8, 175-203.

Sufian, F., \& Habibullah, M. S. (2010). Developments in the efficiency of the Thailand banking sector: a DEA approach. International Journal of Development Issues, 9(3), 226-245. https://doi.org/10.1108/14468951011073316

Sukmana, R., \& Febriyati, N. A. (2016). Islamic Banks vs Conventional Banks in Indonesia : An Analysis on Financial Performances. Jurnal Pengurusan, 47(7), 81-90.

Supriani, I., \& Sudarsono, H. (2018). Analisis Pengaruh Variabel Mikro dan Makro terhadap NPF Perbankan Syariah di Indonesia. Equilibrium: Jurnal Ekonomi Syariah, 6(1), 1. https://doi.org/10.21043/equilibrium.v6i1.3040

Toumi, K. (2019). Islamic ethics, capital structure and profitability of banks; what makes Islamic banks different? International Journal of Islamic and Middle Eastern Finance and Management, 13(1), 116-134. https://doi.org/10.1108/IMEFM-05-2016-0061

Trabelsi, M. A., \& Trad, N. (2017). Profitability and risk in interest-free banking industries: a dynamic panel data analysis. International Journal of Islamic and Middle Eastern Finance and Management, 10(4), 454-469. https://doi.org/10.1108/IMEFM-05-20160070

Trad, N., Trabelsi, M. A., \& Goux, J. F. (2017). Risk and profitability of Islamic banks: A religious deception or an alternative solution? European Research on Management and Business Economics, 23(1), 40-45. https://doi.org/10.1016/j.iedeen.2016.09.001

Uyanık, G. K., \& Güler, N. (2013). A Study on Multiple Linear Regression Analysis. Procedia - Social and Behavioral Sciences, 106, 234-240. https://doi.org/10.1016/j.sbspro.2013.12.027

Vervuurt, J. (2016). Business Cycle Based Portfolio Optimisation (Issue November). Tilburg University.

Wibowo, E. S., \& Syaichu, M. (2013). Analisis Pengaruh Suku Bunga, Inflasi, CAR, BOPO, NPF Terhadap Profitabilitas Bank Syariah. DIPONEGORO JOURNAL OF MANAGEMENT, 2(2), 1-10.

Yanikkaya, H., Gümüş, N., \& Pabuçcu, Y. U. (2018). How profitability differs between conventional and Islamic banks: A dynamic panel data approach. Pacific Basin Finance Journal, 48(July 2017), 99-111. https://doi.org/10.1016/j.pacfin.2018.01.006

Zarrouk, H., Jedidia, K. Ben, \& Moualhi, M. (2016). Is Islamic bank profitability driven by same forces as conventional banks? International Journal of Islamic and Middle Eastern Finance and Management, 9(1), 46-66. https://doi.org/10.1108/IMEFM-122014-0120 